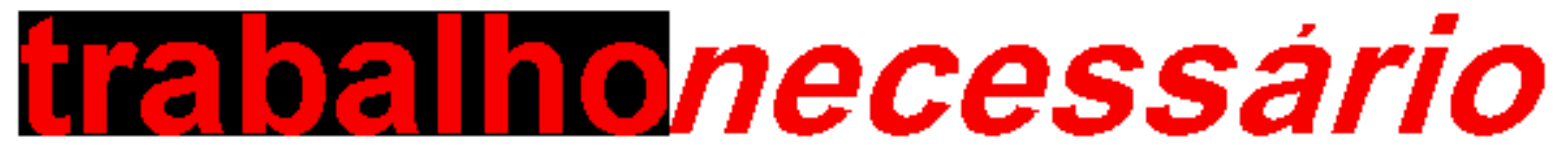

issn: $1808-799 \mathrm{X}$

ano 4 - número 4 - 2006

\title{
CONTORNOS DA RELAÇÃO ESTADO, SOCIEDADE E INTELECTUAIS EM GOIÁS NA DÉCADA DE 1930[1]
}

Rubia-Mar Nunes Pinto $\left(^{*}\right)$

Programa de Pós Graduação em Educação FE/UFF

\section{Resumo}

Neste texto, pretendo discutir as mudanças ocorridas no Estado, em Goiás, no período 1930/1940, momento da construção de Goiânia, as quais estão estritamente articuladas ao papel dos intelectuais no contexto da integração de Goiás à economia nacional. Para tanto, as fontes privilegiadas advém da Revista A Informação Goyana, do dossiê Memória Cultural: Ensaios da história de um povo (1985) e do livro Como Nasceu Goiânia, publicado em 1942 sendo que as reflexões serão orientadas pelo conjunto de concepções de Estado em Antonio Gramsci bem como suas idéias a respeito dos intelectuais. Quanto à organização do texto, optei por subdividi-lo em 03 partes: na primeira, traço algumas características contextuais que possibilitaram a construção de Goiânia. Na segunda, abordo o cenário da construção de Goiânia, na fase 1930/1945, enfatizando os impasses, dificuldades e soluções encontradas pelo Estado e, finalmente, na terceira, discuto o trabalho de alguns intelectuais goianos na propaganda e divulgação do potencial econômico da região.

Palavras-chave: Estado - Intelectuais - Goiânia

Quereis a Capital aqui? Pois bem! Com a lei ou sem a lei, pela força do direito ou pelo direito da força, te-la-eis aqui muito em breve.

Pedro Ludovico Teixeira

As palavras do interventor de Goiás, Pedro Ludovico Teixeira, expressam com clareza a obstinação deste governante em construir, na década de 1930, uma cidade moderna e torná-la a nova capital do estado de Goiás. Pedro Ludovico Teixeira, sem dúvida, assumia, com rara determinação, o projeto político e social de uma classe média emergente e letrada que surgia na Região. A este grupo aliavam-se os fazendeiros de arroz e milho do sul/sudeste do estado, a quem interessava o deslocamento do poder 
político estadual que, então, era monopólio da oligarquia caiadista que estava sediada em Vila Boa de Goyaz (atual Cidade de Goiás ou ainda Goiás Velha, como é reconhecida no imaginário popular dos goianos). Segundo DAHER (2003: 33),

Do ponto de vista social, os moradores dessas regiões [sul/sudeste do estado] que detinham a maior parte da economia goiana, sentiam a necessidade de uma sede urbana moderna, com todas as benfeitorias físicas, educacionais, de saúde, culturais, enfim, um local onde a classe média emergente pudesse se estabelecer e usufruir desses benefícios urbanos.

Os interesses políticos e econômicos na construção de um novo centro de poder estadual prevaleceram sobre a proposta de reformar a velha Vila Boa já que, de fato, o que se buscava era a dinamização de uma capital voltada para os interesses do sul/sudeste de Goiás, ou em outras palavras, para o centro econômico do estado. Para Pedro Ludovico, a recuperação de Vila Boa era 'impossível' conforme demonstram suas palavras em relatório enviado ao então Chefe do Governo Provisório, Sr. Dr. Getúlio Vargas em 1933:

Entre inverter os recursos do povo na remodelação impossível de uma cidade, velha e inafeiçoável às utilidades da vida moderna e aplicá-los na construção de uma capital nova, que seja verdadeira metrópole de seu progresso - a lógica, o senso das realidades, o interesse comum e o futuro do próprio Estado gritam ao administrador bem intensionado (sic) qual a solução que the cumpre adotar. Ai não cabe nenhuma hesitação (MONTEIRO, 1942).

Tão significativa da obstinação do interventor quanto suas palavras é a procura é a contratação de alguns dos melhores e mais conceituados profissionais[2] da então nova área de urbanismo no Brasil para a elaboração do projeto da nova capital bem como para a implementação de sua construção. Segundo vários autores (RIBEIRO, 1996; BRUANT, 1996; ANDRADE, 1996; PEREIRA, 1996), a aplicação do urbanismo aos problemas das cidades brasileiras já se fazia presente, no começo do século $X X$, em alguns dos centros mais desenvolvidos do País (Rio de Janeiro, São Paulo, Minas Gerais, Espírito Santo, Paraná, Bahia), mas como pensar esse dado no caso goiano? Afinal, Goiás era, então, uma região muito afastada - geográfica, econômica e culturalmente - dos grandes centros, possuía uma precaríssima estrutura de comunicação e transporte além de uma péssima situação financeira.

A contratação de urbanistas de renome nacional revela o interesse em construir, nos rincões do hinterland[3], uma cidade sintonizada com o que de mais moderno havia, não somente no Brasil, mas no mundo. Revela ainda que Pedro Ludovico e os grupos que Ihe davam respaldo político e ideológico estavam sintonizados com o potencial civilizador da cidade e com a força educativa e pedagógica dos espaços urbanos na transformação das mentalidades e dos costumes. À nova Capital, assim, foi destinada, desde sua idealização, o papel de educar a sociedade goiana para os novos parâmetros de sociabilidade que vicejavam por todo o País sintetizadas na ideologia do progresso. As edificações (prédios públicos e residenciais) da nova Capital deveriam representar [...] os marcos de um avanço [...], e portanto, devem ser colocadas no ponto mais próximo possível dos fins colimados: a sincronização de nosso progresso com o dos centros mais avançados do Brasil; e assim, impressionar bem o 
espírito de nossa gente para fazê-las sentir com a evidência dos factos (sic) o quanto nós estamos atrazados (sic) em relação àqueles centros, e com argumento insofismável das cousas feitas, convencê-los que este avanço que se tenta é realizável. Esta função profundamente psicológica, profundamente educativa, que estas obras necessariamente têm que cumprir, em sido motivo de nosso zelo em dar-Ihes um acabamento o quanto possível perfeito[4].

A construção de Goiânia estava vinculada ao ímpeto civilizatório e modernizador que, então, varria o País. Por toda à parte, cidades eram reformadas. As cidades brasileiras procuravam ser modernas suplantando o modelo colonial do urbano para, assim, instituir uma nova relação entre os âmbitos público/privado. Tratava-se, na verdade, de instituir uma nova ordem social. Um dos paradigmas da modernidade orientou esta tentativa: a idéia que o Estado Nacional pode "[...] mudar a sociedade e manobrar o social através do imaginário de um futuro alternativo" (HOLSTON, 1993: 03). A nova Capital goiana deveria, por isso, inovar em tudo quanto fosse possível diferenciando-se de outras capitais estaduais e não deveria ter

[...] nem a vergonha dos mucambos de Pernambuco, nem as taperas de Minas, nem as arapucas dos morros do Pinto da Favela. Ali não há lugar paras as febres da Baixada Fluminense, nem para as verminoses dos estados nordestinos, nem para a promiscuidade das ruas da Alfândega e de São Pedro [...] (Austriclinio Brandão, Jornal A tarde, de Ribeirão Preto, 1937 citado em MONTEIRO, 1942).

A idéia da transferência da Capital não era propriamente uma novidade na região. Segundo os historiadores goianos, a idéia de uma mudança na sede do poder estadual foi ventilada em 1749, pelo Conde dos Arcos - então governador da província de Goyaz -, voltando à cena em 1865, após a independência do Brasil através do presidente do estado Couto Magalhães. Argumentava-se que Vila Boa era um local inapropriado para sediar o governo goiano, pois, "a cidade encontrava-se cercada por uma cadeia de montanhas, que impossibilitava sua expansão e dificultava o acesso a ela” (DAHER, 2003: 26).

De uma determinada interpretação historiográfica[5] - hoje, predominante nos estudos sobre a história de Goiás - a imagem de uma nova capital foi construída na mente de muitos líderes políticos e da escassa elite letrada da região que viram, nesta mudança, a possibilidade de superação da idéia e do sentimento de decadência e atraso que, sempre, estigmatizaram, Goiás e sua população[6] (PALACíN, 1986; CHAUL, 2001; PEREIRA, 2002).

Em todas as tentativas para construção de uma nova capital, a questão esbarrou no alto custo do empreendimento e nas enormes distâncias que separavam Goiás dos centros mais desenvolvidos do Brasil: nem o reino português nem o governo imperial brasileiro quiseram ou puderam investir no projeto e a empobrecida província de Goyaz, sozinha, também não poderia levá-lo a termo. Mas com a Revolução de 1930 e a ascensão de Getúlio Vargas e, em Goiás, de Pedro Ludovico Teixeira, a situação se 
alterou e a utopia tornou-se possível.

Este contexto permite o delineamento de inúmeras questões: O que havia mudado se Goiás continuava a ser um estado pobre e isolado do restante do País? Porque o governo central brasileiro, por muito tempo, insensível aos apelos mudancistas, apoiou a construção da "filha mais moça e bonita do Brasil"[7]? E no interior do projeto de construção, quais foram os agentes que trabalharam para isto e de quais os meios e argumentos se valeram para tornar possível a construção da nova cidade e a transferência da capital?

As questões anteriormente colocadas servem como pano de fundo para a discussão proposta neste trabalho, qual seja a gênese do estado Moderno em Goiás na década de 1930, momento em que a busca da soberania começava a ganhar os contornos de uma articulação entre coerção e consenso. A partir de 1930, com Pedro Ludovico Teixeira, esta busca ocorre, principalmente, através da ação intelectuais que se empenharam na propaganda do Estado e de seu governo e também através da ação do próprio governante - Pedro Ludovico, ele próprio um intelectual - que estabeleceu com as massas subalternas uma relação de paternalismo que lhe permitiu angariar os apoios de que precisava para a consecução de seu projeto.

Tomando por base as concepções e idéias gramscianas, é possível perceber, na sociedade goiana daquele período, algumas características do que o filósofo italiano considerava uma sociedade oriental, na qual evidencia-se a inexistência de uma sociedade civil. Nestas sociedades, que não conhecem a experiência da democracia, o Estado é autoritário, atuando basicamente através da coerção e a sociedade civil 'primitiva e gelatinosa', conforme dizia Gramsci (1999).

Para compreender como a utopia de Goiânia tornou-se possível na década de 1930, é preciso contextualizar, ainda que rapidamente, o cenário político, econômico e cultural que viabilizou a edificação de Goiânia na era Vargas, ressaltando o significado da nova capital goiana no projeto de interiorização e, conseqüentemente, na ampliação do capitalismo para além do Brasil litorâneo. Antes de tudo, porém, faz-se necessário explicitar, de modo geral, as características do domínio da oligarquia Caiado em Goiás, pois, somente assim é possível perceber as mudanças que ocorreram após 1930.

Os Caiado governaram de 1917 a 1930 de acordo com a tradição oligárquica que sempre dirigiu Goiás, ou seja, de acordo com os interesses dos ricos proprietários de terra da região que, no caso, tratava-se de grandes criadores de gado. Estritamente ligado a estes interesses, Antonio Ramos Caiado (Totó Caiado), Presidente do estado, recusava-se a promover uma atuação significativa no sentido da integração de Goiás ao restante do País bem como em desenvolver políticas sociais que atingissem a maioria da população. $A$ 
situação do estado naquele momento era descrita como inercial, estagnada.

Totó Caiado governava com mão de ferro e totalmente afastado das necessidades e anseios das classes subalternas da Região como também dos interesses dos fazendeiros que começavam a desenvolver a atividade agrícola no sul/sudeste do estado que, desde os anos 1910, passava por um processo de desenvolvimento, o qual foi estimulado pela proximidade destas sub-regiões com o Triângulo Mineiro e pelo fato da Estrada de Ferro da Mogiana já por ter ali chegado. Esses municípios fizeram intensa oposição à oligarquia Caiado e forneceram a base política para Pedro Ludovico (BORGES, 2004). Mas faltavam vias rodoviárias que contribuíssem para o escoamento da produção bem como para a chegada, a Goiás, do propalado progresso que naquele momento significava, principalmente, máquinas automotivas[8] e tudo que elas poderiam trazer.

Assim, o ponto nevrálgico da questão consistia, segundo visão da época, na abertura de vias de transporte por onde pudesse escoar a produção agrícola da Região. A recusa de Totó Caiado em construir estradas e levar os trilhos da estrada de ferro até as terras goianas se justificava pela sua adesão ao grupo de criadores de gado: o boi se autotransportava não necessitando de vias de transporte para chegar ao seu destino. Por isto a incorporação produtiva de Goiás permaneceu precária, parcial e limitada a poucos produtos (basicamente, o gado e seus derivados e o arroz produzido no sul/sudeste do estado).

Na condição de poder oligárquico, os Caiado se valiam do poder público para proteger os grandes latifundiários - inclusive, através da grilagem de terras - reprimindo com violência as manifestações que se apresentassem contrárias aos interesses das oligarquias rurais. É exemplar, neste sentido, a repressão, pela força policial e pela máquina jurídica do estado, do Movimento de Santa Dica no inicio da década de 1920[9] e também o expurgo de políticos em São José do Duro[10]. Na verdade, pode-se perceber, em Goiás, uma quase total ausência de Estado em seu sentido moderno, o qual implica na existência de parâmetros administrativos (como burocracia e planejamento) e também, como aponta Gramsci (1995), implica na busca de construção de uma hegemonia cultural.

O Movimento de Trinta promoveu as condições para o afastamento de Totó Caiado e concretizou as mudanças há muito requeridas pelos opositores da família Caiado. É aqui que é necessário atentar para as novas formas que o Estado assume a partir da gestão de Pedro Ludovico Teixeira, em particular, enfatizando a busca da construção de uma soberania baseada na articulação de coerção/força e consenso/consentimento. Por sinal, o interventor soube, como poucos, congregar elementos que permitiram, a ele, o exercício de um governo autoritário, mas que contou com o apoio da maioria da população goiana. O Estado, basicamente representado na figura de seu dirigente máximo, soube atuar nas 
rotinas materiais e subjetivas dos indivíduos, principalmente, em Goiânia, conquistando adesão e apoio da maioria da população. A crônica de Bernardes Elis (1985: 61) é expressiva dessa atuação.

Aqui [Goiânia], as condições de vida eram precárias e difíceis. O governo teve que providenciar as mais simples coisas. Para garantir alimento, organizou uma granja que fornecia leite, ovos, aves, verduras, ao tempo muito vasqueiros. A partir daí, por vários anos adiante, criou-se o hábito de se constituir o governo no árbitro dos problemas da cidade, desde briguinhas por beira de cama dos casais, até questões de dinheiro. Dizia-se então que um caminho ligava cada cozinha ao gabinete de Dr. Pedro, que estava paternalmente a par de tudo. E como estendia suas asas na defesa de uma pessoa, outras vezes dava prazo de 12 ou 24 horas para alguém deixar a cidade.

A partir desta rápida contextualização é possível entender a emergência de uma nova organização do poder público, em Goiás, na qual a busca do consenso se concretiza na proposta e construção de uma nova capital bem como na utilização ostensiva da propaganda, efetivada por intelectuais goianos, que visavam colocar "diante dos olhos dos capitalistas, dos industriaes (sic) e commerciantes as possibilidades econômicas sem conta do estado mais central e menos conhecido do Brasil"[11]. A este grupo de intelectuais pode ser creditada uma considerável contribuição para a concretização de Goiânia uma vez que, estando empenhado em traçar um programa que indicasse os rumos de uma nova política econômica para Goiás, realizou um trabalho de divulgação e propaganda que atraiu, para o estado, além de contingente populacional, os investimentos do capital nacional e até mesmo internacional. A entrada de capital nacional viabilizou, até certo ponto, as condições econômicas e demográficas necessárias para a construção de Goiânia, a qual estava intimamente relacionada à definitiva inserção de Goiás na economia brasileira e no capitalismo mundial.

Refletir sobre o papel dos intelectuais como mediadores entre sociedade civil e sociedade política implica no reconhecimento da pertinência do filósofo italiano Antonio Gramsci, em especial, suas concepções acerca do Estado Moderno bem como aquelas que se referem ao papel dos intelectuais na organização da cultura, particularmente, da cultura política. O conjunto de idéias de Gramsci se mostra pertinente pelo alargamento proposto por este autor - da concepção de Estado herdada da tradição marxista, segundo a qual, o Estado atua exclusivamente na esfera da coerção e da violência. Para Grasmci (1991), ao contrário, o estado abrange também a esfera do consentimento ou consenso na construção da soberania. Por outro lado, o alargamento da concepção de Estado implica também em uma ampliação da noção de intelectuais, os quais, para o filosofo italiano, se apresentam como

[...] 'comissários' do grupo dominante para o exercício das funções subalternas da hegemonia social e do governo político, isto é: 1) do consenso 'espontâneo' dado pelas grandes massas da população orientação impressa pelo grupo fundamental dominante à vida social [...];

2) do aparato de coerção estatal que assegura 'legalmente' a disciplina dos 
grupos que não 'consentem', nem ativa nem passivamente, mas que é constituído para toda a sociedade, na previsão dos momentos de crise no comando e na direção, nos quais fracassa o consenso espontâneo (GRAMSCI, 1995: 11).

\section{Construção De Goiânia E Expansão Capitalista Na Década De 1930: Gênese Da Formação Da Formação Do Estado Moderno Em Goiás.}

Em 1930, com a ascensão de Getúlio Vargas ao poder inaugurou-se, no Brasil, uma dinâmica na qual a presença do poder público se intensificou em cada estado da federação. Políticas e programas oficiais, como a Marcha para o Oeste, foram estendendo a racionalidade e a autoridade do aparato administrativo com vistas a efetivar o Estado Nacional. Assim, em diferentes sub-unidades estaduais, como ocorreu em Goiás, a presença do Estado foi materializada nos incentivos à vinda de capitalistas e trabalhadores, na distribuição de terras, na coordenação dos assentamentos e na viabilização do surgimento de cidades

[...] são as iniciativas estatais que potencializam interesses e regulam as solidariedades e os conflitos, ditam os parâmetros e leis que, enfim, resultam não apenas na própria feição adminstrativa-burocrática e policial do Estado - que fiscaliza, arrecada, planeja e dinamiza o desenvolvimento das forças sociais mas também na sua capacidade de cumprir as funções de regulação e legitimação da ordem social (BORGES, 2004: 1986)

Pode-se perceber, de acordo com Francisco Carlos Teixeira da Silva (1999), que novas preocupações assolavam o Estado Nacional: a questão do mundo rural se impunha como preocupação central. Diversos argumentos compunham o substrato destas preocupações sendo que a primeira delas era a percepção de um mundo em crise econômica e em evidente processo de aguçamento de conflitos internacionais. Uma tal situação impunha a necessidade de criar as condições para o auto-abastecimento de alimentos para o País. Neste contexto, era preciso colonizar internamente o País expandindo as fronteiras agrícolas. Por isso, produzir mais e para o mercado interno, tornou-se uma meta do Estado.

Além disso, eram avaliados os riscos de uma ação imperialista a que estava exposto um País formado por vastos territórios desocupados e de uma fronteira oeste Goiás, Mato Grosso, Rondônia, Amazonas - praticamente abandonada. Alberto Torres e Oliveira Vianna, por exemplo, foram intelectuais que chamaram a atenção para o risco de a geografia de um País escassamente povoado e também para a presença de colônias estrangeiras que se constituíam em bases para uma ação imperialista. Assim, a atuação do Estado, a partir de 1930, voltou-se para os espaços vazios do Centro-Oeste, para o interior do Nordeste e para a Amazônia, secundarizando as preocupações com as áreas de economia próspera e de urbanização já consolidada do eixo Centro-Sul.

Neste contexto, a incorporação de novas áreas do interior do País ao espectro da 
nação se constituiu em um objetivo estratégico da ideologia do progresso assumida pelo Estado brasileiro na era Vargas. Com base em uma perspectiva industrializante, o Movimento de Trinta faz surgir, segundo lanni (1977), as condições para o desenvolvimento do Estado burguês, o qual oferecia elementos para o desenvolvimento do setor industrial. A dinamização da industria, no entanto, se desenvolvia no centro-sul do País, o que exigia que novas regiões brasileiras cumprissem o papel de produtor para o mercado interno em substituição ao papel desempenhado, até então, pelas áreas que se industrializavam. Foi esse o papel assumido então por Goiás. Desta forma, enquanto o centro-sul brasileiro se efetivava como periferia do capitalismo mundial, outras regiões, como o centro-oeste se efetivavam como periferia da periferia.

Tomando por base as concepções de José de Souza Martins (1975), a ocupação das regiões goianas ao capitalismo mundial deu-se a partir das frentes de expansão, as quais se constituíam em uma exigência das transformações econômicas oriundas da industrialização do centro-sul e também pela expansão da sua economia agrícola, notadamente a cafeeira. Foram estas transformações que, afinal, sustentaram a ocupação de áreas produtivas no interior do País e, conseqüentemente, sua incorporação à produção capitalista[12].

A Marcha para o Oeste foi o programa oficializado pelo Governo Vargas para possibilitar a ocupação produtiva do interior brasileiro, a qual era considerada fundamental para os propósitos de unificação nacional alimentados por Vargas. Conquistar o oeste implicava em uma presença incisiva do Estado na vida política e econômica de cada unidade estadual do País. No caso de Goiás, o projeto de unificação nacional introduziu o discurso do progresso, disponibilizando amplos incentivos à imigração e à ocupação produtiva da terra sendo que a construção de Goiânia está vinculada a este movimento.

A ‘Revolução' de Trinta chegou a Goiás por força da intervenção da coluna mineira [13] que, não encontrando resistências, instalou uma junta governativa composta de políticos opositores da oligarquia Caiado. Pedro Ludovico, um dos membros da Junta Governativa, foi depois nomeado interventor do estado. Sua principal proposta: a construção de uma nova cidade e a transferência da capital. Seu argumento: a problemática localização geográfica de Vila Boa e sua inadequação aos imperativos da higiene.

Médico formado pela Faculdade de Medicina do Rio de Janeiro, meca do higienismo no Brasil, Pedro Ludovico estava sintonizado com o papel que a medicina social vinha assumindo no governo das populações e utilizou-se, para justificar e convencer a sociedade goiana da necessidade da construção de Goiânia e conseqüente transferência da capital, do discurso médico-higienista focalizando as condições anti-higiênicas e insalubres da cidade de Goiás e a necessidade de melhorar as condições de vida e saúde 
da população. Conforme Campos (2002: 170), o saber médico de Ludovico permitiu a ele examinar o a cidade de Goiás "como a um doente" destacando o modo de vida, as moradias, as verminoses, a falta de condições sanitárias, a suposta indolência da população, entre outros para, a partir daí, defender a construção de Goiânia - que arrancaria Goiás do atraso e da decadência constituindo exemplo a ser seguido pelos interiores goianos - como profilaxia à doença.

No entanto, a maioria dos estudiosos da história goiana considera que "o projeto de construção de Goiânia tem [...] razões, sobretudo políticas, que na verdade se sobrepõem às explicações fundadas em pretextos sanitários ou geográficos utilizados pelo interventor para angariar apoios à mudança da capital" (BORGES, 2004; CAMPOS, 2002, BERNARDES, 1989). Na verdade, a construção e a mudança da Capital atendia a uma dupla finalidade de Pedro Ludovico: no plano interno, foi a concretização do ideário mudancista, da vitória sobre a oligarquia Caiado e da promessa de progresso e civilização que lhe permitiram a permanência no poder com o apoio da população e de expressiva fração da classe política goiana. Ao mesmo tempo, externamente, alavancou a migração e o investimento de capital nas terras goianas, promovendo uma modernização das relações de trabalho e poder.

A construção da nova capital satisfazia aos anseios de expansão do sistema capitalista. Internamente o estado, na figura de seu interventor, Pedro Ludovico Teixeira, não poupou esforços para incrementar a indústria da construção civil e os serviços a ela subordinados. Era necessário modernizar as relações de trabalho e poder. Nesta perspectiva, o Estado assumia papel preponderante como mediador na relação capital e trabalho, utilizando-se de meios propagandistas e incentivos fiscais para atrair capital de outros estados (BERNARDES, 1989: 30).

Havia também outras propostas, como a abertura de estradas - aspecto considerado essencial para a integração da produção estadual a economia nacional - e os incentivos à produção agrícola. Entretanto, estas propostas obtiveram, de fato, pouca atenção por parte do governo estadual: a construção de Goiânia absorveu quase toda a arrecadação do estado durante todo o governo Pedro Ludovico (1930/1945). De acordo com estudiosos, Goiânia foi a única ação realmente planejada na configuração, à época, do estado de Goiás já que os incentivos na área agrícola não se constituíam, de fato, em planos de governo. No entanto, apesar das promessas de civilização e progresso para a população de Goiás, a ascensão de Pedro Ludovico não proporcionou, segundo Silva (2001: 135), alterações no conteúdo de classe do Estado, continuando a beneficiar os proprietários de terra.

Ele [o Estado] continua favorecendo as oligarquias. Estas continuaram como as únicas beneficiárias da política econômica do estado. O que elas perderam foi a capacidade do controle direto do poder público, uma vez que passaram a depender, em suas decisões, do poder central. Perderam a 'carta branca' que Ihes dava total liberdade de ação no plano estadual, mas 
continuaram donas do baralho e, se suas possibilidades de barganha com o poder central diminuíram em benefício deste, continuavam como parceiros na dominação sobre o restante da população.

O tão festajado progresso que Goiânia prometia para a população do estado alcançava apenas os proprietários da terra, os grupos oligárquicos e os capitalistas em geral. Era, em suma, tão somente a noção burguesa de progresso que chegava a Goiás e como tão bem alerta Gramsci (1978: 45), a ideologia do progresso já não era, à época da construção de Goiânia, uma ideologia democrática

[...] não no sentido de que se tenha perdido a fé na possibilidade de dominar racionalmente a natureza e o acaso, mas no sentido [...] de que os 'portadores' oficiais do progresso tornaram-se incapazes deste domínio, já que suscitam forças destruidoras atuais tão perigosas e angustiantes quanto as do passado [...] tais como as 'crises', o desemprego, etc." (grifos do autor).

Por sua vez, não foram poucos os problemas e impedimentos que Pedro Ludovico Teixeira enfrentou para concretizar sua obstinação. A falta de verbas e de material de construção e escassez e/ou inexistência de mão-de-obra, as pressões dos proprietários de terra que tentavam, durante toda a construção, autorização oficial para a montagem de loteamentos e, por fim, as invasões por parte da população de migrantes que acorreu à Goiânia destacam-se, neste contexto, estando todas estas problemáticas atreladas e dependentes umas das outras. Além disso, o projeto de mudança encontrou uma tenaz resistência e oposição de políticos coordenada por políticos de Vila Boa.

O maior problema, sem dúvida, estava na questão econômica e causou, entre outras conseqüências, o endividamento do estado que buscou, por várias vezes, empréstimos para concretização das obras. A falta de recursos acabou por retardar, inclusive, o término das obras e consolidou a parceira do Estado com a iniciativa privada, a qual serviu de pano de fundo para o estabelecimento das relações de exploração capitalistas. De fato, como alerta DAHER (2003: 214) "a construção de Goiânia ficou [...] sob a responsabilidade da iniciativa particular [e] a idéia de o Estado controlar as benfeitorias urbanas, conforme preconizam as escolas de urbanismo moderno, não ocorreu $[\ldots] "$ ".

Somada ao problema do financiamento, estava a inexistência de mão de obra especializada ou mesmo em número suficiente para a construção da cidade, a qual demandou, aproximadamente, quatro mil operários[14]. Além da escassez de braços, Campos (1980) ainda ressalta que havia a inexistência de mão-de-obra especializada na construção civil: "[...] não havia mestre-de-obra, nem pedreiro, nem pintores, nem carpinteiros; nem eletricistas e nem encanadores". O deslocamento, para Goiás, de um contingente de homens aptos ao trabalho de construção civil foi a solução encontrada e 
teve como elemento fundamental uma política de imigração - sustentada sobretudo pela propaganda - que, levada a cabo, produziu uma abundância de mão de obra que teve como conseqüência a formação de um exército de reserva, o qual serviu para o estabelecimento de relações capitalistas de exploração dos trabalhadores da construção civil a medida que a cidade era edificada.

Esses trabalhadores, de acordo com Chaul (2001), enfrentaram dificuldades relacionados ao transporte e locomoção para Goiás, a péssima estrutura de vida expressa nos locais de moradia e alojamento[15] e, por fim, a falta e/ou atraso do pagamento de salários por parte do governo estadual. A situação operária era reflexo da situação de um estado que, na periferia da periferia do capitalismo, fazia surgir uma cidade moderna as custas do sacrifício, principalmente, dos operários e de suas famílias. "Vivendo uma vida de miséria, [...] o operariado sobrevivia de empréstimos, vales e promessas" (CHAUL, 2001: 111), mas mantinha-se na construção porque a abundância de mão-de-obra favorecia o Estado e os capitalistas. A fala de Vitorino Freitas, carpinteiro que chegou a Goiânia em 1939[16] relata o cotidiano daqueles trabalhadores revelando a exploração pela agiotagem e pela mais valia.

[O pagamento\} não era feito mensalmente nem semanalmente. Que eu trabalhei para o Estado, eu recebia mais ou menos de quatro em quatro meses eu recebia salário de um mês! Tanto que tinha aí um agiota de nome Raimundo Nunes, um piauiense. Era o meu agiota. Todo mês, eu vendia o meu salário do mês para ele, com desconto de 20 por cento. Dava procuração e vendia o salário pra ele e me mantinha mais ou menos durante a semana fazendo servicinhos que a gente chamava de biscate. Eu era biscateiro aos domingos e feriados. Trabalhava quase dia e noite, as madrugadas também.

Também como forma de resolver a questão da falta de pagamento de salários foi adotado o sistema de autorização de pagamento (vales), através dos quais se tornava possível, ao trabalhador, a compra de gêneros de primeiras necessidades em armazéns e estabelecimentos comerciais. O governo estadual, porém, também não realizava, ao tempo combinado, o pagamento aos comerciantes, os quais passaram a cobrar juros de 20, 30 e até 40 por cento dos trabalhadores. Formava-se, assim, uma dinâmica de exploração no qual os salários - já minguados - não faziam frente às necessidades dos trabalhadores, os quais, endividados, ficavam presos às obras.

Nesse cenário se concretizaram as relações capital-trabalho na nascente Goiânia onde conviveram a desvalorização dos salários por meio da emissão de vales, a mais-valia e a formação de um contingente operário de reserva para o Estado e para os proprietários de terras e do capital. Assim, enquanto as práticas capitalistas se misturavam ao domínio político baseado na propriedade da terra, a mentalidade agrária ia absorvendo a ideologia de progresso conduzida e difundida pela classe média emergente em Goiás.

Apesar dos problemas e das dificuldades, o Estado obteve apoio e adesão de 
amplos setores da população. É aqui que se ressalta o papel dos intelectuais, entre eles o próprio Pedro Ludovico, na construção do consenso. Médicos, militares e advogados, em sua maioria, formados no Rio de Janeiro e com atuação na área de jornalismo, estes intelectuais ou compuseram o quadro de assessores do governo de Trinta, em Goiás, ou mantiveram estreitas relações com o poder público estadual e trabalharam, ativamente, para divulgar o estado de Goiás, em particular, suas riquezas naturais e seu potencial econômico. É esse, aliás, o traço comum na atuação deste grupo: eles visavam, sobretudo, a ocupação produtiva do estado e, para tanto, realizaram um amplo programa de propaganda e divulgação de suas possibilidades em jornais e revistas nacionais e mesmo estrangeiras.

\section{Os Intelectuais Em Goiás: Forjando O Consenso}

Em meados do século XX, a inexpressiva população de Goiás vivia dispersa em um vasto território e era composta, em sua maioria, de camponeses analfabetos e pobres. Em uma população que vivia nas zonas rurais, em uma situação de quase isolamento em relação ao restante do País e do mundo, a presença de pessoas letradas era uma raridade sendo que, de acordo com os estudiosos da história goiana, a escolarização ainda não se constituía em uma aspiração das famílias pobres que viviam na Região. Por sua vez, as famílias proprietárias de terra costumavam oferecer, a seus filhos e filhas, as primeiras letras através de perceptores, escolas privadas e também do alfabetismo praticado pela mãe. A partir de 1870, estas famílias e também aquelas pertencentes a uma classe média que começava a emergir enviavam, pelo menos, um de seus filhos para estudar em centros mais desenvolvidos como o Rio de Janeiro[17] (NEPOMUCENO, 2003).

Na volta a Terra, estes jovens assumiam, quase sempre, funções políticas e sociais importantes e destacadas no contexto da política e da cultura goianas ou, sediando-se na Capital da República, continuavam ligados a Goiás através do trabalho de propaganda e divulgação do estado voltado, essencialmente, para sua ocupação produtiva. Naquele momento, principalmente, pode-se considerar que os intelectuais goianos[18] podem ser pensados nos marcos da teoria gramsciniana sobre a cultura. Segundo Gramsci (1995), o tipo de intelectual rural existente em regiões latino-americanas se qualifica como intelectual do tipo rural que, ao contrário de se ligar às massas camponesas ou pequeno burguesa de cidades, "são ligados ao clero e aos grandes proprietários de terra".

Assim, organicamente relacionados aos detentores do poder político e econômico local, estes intelectuais trabalharam arduamente pela ocupação produtiva da terra e, conseqüentemente, pela modernização das relações de trabalho e poder sem, no entanto, questionar as estruturas de dominação que, então, sujeitava a população pobre. Em outras palavras, ao falar sobre uma região atravessada pelos conflitos de terra - cuja mediação estava nas mãos de políticos vinculados aos grandes proprietários e mesmo nas mãos 
fazendeiros - estes intelectuais contribuíram para divulgar a visão de mundo daqueles que exerciam o poder político local ignorando o papel destes na opressão e dominação dos camponeses.

A ação dos intelectuais em favor da ocupação produtiva de Goiás não teve início, contudo, com a proposta da construção de Goiânia nos anos 1930. A partir deste momento, esta ação apenas se intensificou porque encontrou no Estado os incentivos necessários bem como a vontade política de realizar mudanças. Na verdade, desde o final do século XIX/início do século XX[19], logo depois da instauração da República, um grupo de intelectuais goianos que estudava e/ou trabalhava na Capital Federal começava a dar mostras de uma crescente insatisfação com o pouco prestígio do estado de Goiás no contexto das discussões que ocorriam no Rio de janeiro. Além disso, o governo central ignorava Goiás em, praticamente, todos os sentidos.

Goiás era, então, uma região desconhecida. A imprensa da Capital Federal pouco falava da Região e quando o fazia, geralmente, cometia equívocos e erros grosseiros como confundi-la com o estado de Mato Grosso. Esta situação provocava, neste grupo de intelectuais, muitos ressentimentos já que consideravam que Goiás era um estado pleno de recursos naturais sendo imensas as possibilidades econômicas geradas por estes recursos. Mas a ignorância das elites intelectuais, políticas e econômicas a respeito da região impedia que tais possibilidades fossem exploradas, o que, em última instância, impedia que Goiás contribuísse para o engrandecimento da nação brasileira (NEPOMUCENO, 2003). Aliado a suas riquezas naturais, sua localização geográfica - no centro do País - tornava Goiás, na visão destes intelectuais, uma região potencialmente importante para a afirmação da nacionalidade.

Era preciso, então, tornar o estado conhecido fazendo a propaganda de suas tradições, história, folclore, mas acima de tudo, de suas potencialidades econômicas. 0 trabalho jornalístico se mostrava pertinente para o alcance desse objetivo. Escrevendo para jornais e revistas publicadas no Rio de Janeiro, os jornalistas goianos esperavam ampliar o conhecimento sobre Goiás e, assim, estimular processos de imigração de pessoas e capital para 'o grande estado do centro do País'. O desejo destes intelectuais fez surgir, inicialmente, a Revista Brazil Central que foi teve publicado um único número em 1891 definindo-se em seu editorial de lançamento como "revista mensal consagrada aos interesses de Goyaz". O projeto desta Revista foi idealizado no interior da Escola Militar da Praia Vermelha quando Henrique Silva e outros intelectuais goianos freqüentaram esta Escola (NEPOMUCENO, 2003). O editorial[20] do único número publicado da revista Brazil Central afirma categoricamente que

No regimen decahido, Goyaz não entrou de facto na communhão nacional 
com o prestigio de uma província, nem para elle foram das mais respeitosas as considerações políticas, nem das mais importantes as maquias dos orçamentos, tão à mão larga dispensada às antigas províncias pelos governos autoritários do extincto império. Depois de quase convertido quasi em uma desnecessidade nacional foi Goyaz [...] communmente designado pelos poderes centrais para palco de estréa parlamentar de proteccionados políticos [...] que [...] representavam nas câmaras o nosso ubérrimo Estado, indifferentes ao seu desenvolvimento, já por serem, na maiorira, estranhos ao seu valor. Mesmo aqui, na própria Capital, imprensa e povo julgavam Goyaz, pela opinião lamentável dos governos [...] uma verdadeira possessão do território, demasiadamente custosa aos cofres públicos e cuja existência era tão só atestada nos mappas eleitoraes dos ministros... Divorciada dos interesses vitaes da nação, interceptada [...] por uma vasta facha de terra despovoada que a insulava da vida activa de suas co-irmãs; sem portos marítimos ou fluviaes que lhe facultassem a concurrencia dos seus inestimáves productos nos nossos grandes mercados; sem meios fáceis de transporte, sem concessões, abandonada e só [...] como [...] prosperar??! (sic).

Essa situação de descaso e desconhecimento não havia sofrido alterações significativa em 1917 quando o projeto desta revista foi retomado por um grupo de jornalistas, coordenados pelo mesmo fundador da Brazil Central, Henrique Silva. Eles fundaram, então, a Revista $A$ Informação Goiana, a qual pretendeu se constituir em um órgão temático especializado no Brasil Central, particularmente Goiás, com finalidades política e publicitária; logo, educativa. Mais precisamente, Henrique Silva e seus colaboradores pretendiam, conforme afirma Nepomuceno (2003: 35), era "[...] tornar conhecidas as riquezas naturais do estado, indicar e descrever o local onde poderiam ser encontradas e, mais que isso, chamar a atenção das autoridades políticas e dos capitalistas para o estudo e, simultaneamente, a exploração dessas riquezas' (NEPOMUCENO, 2003). Em seu 'artigo-programa', publicado em seu primeiro número, os editores de $\mathrm{A}$ Informação Goyana justificavam seu aparecimento a partir da

[...] necessidade que havia de um órgão informativo [...] das [...] riquezas nativas do hinter-land brasileiro - Essa vastíssima região quasi desconhecida $[. .$.$] e que no entanto possui [...] fortes elementos para se incorporar às$ correntes progressivas das [...] prosperas zonas do paiz. [...]. Goyaz occupa o centro geometrico do Brasil, e não carece de razões geográphicas para representar [...] um importante papel social e econômico na grandeza futura de nossa nacionalidade (sic).

Os fragmentos a seguir demonstram que as riquezas minerais eram o elemento que, na visão daqueles intelectuais, tornava o estado de Goyaz potencialmente promissor para a exploração econômica e para a afirmação da nacionalidade.

Dentro da immensidão do Brasil, Goyaz, ainda despovoado, cheio de fabulosoas riquezas, é um verdadeiro e maravilhoso mundo. [...] a Revista, 
sempre tão documentada e interessante, procura mostrar o que é esse vasto e admiravel trecho do território nacional (sic) (A INOFRMAÇÃO GOYANA, 1923: 103).

A riqueza mineralógica da província de Goyaz não é assumpto para ser tratado perfunctoriamente. Esta província contém em seu seio um tratado completo de mineralogia, e tão pródiga é a sua riqueza que bem se póde dizer uma vasta mina de ouro, de pedras e metaes preciosos [...] (sic) (A INFORMAÇÃO GOYANA, 1917: 07-08).

Não resta dúvida [...] que Goyaz possue (sic) todas a fontes de riquezas que a terra produz no mundo inteiro (A INFORMAÇÃO GOYANA, 1917: 01).

A Revista, que assumiu a postura de neutralidade política[21] pretendeu, de fato, construir um programa de desenvolvimento econômico para Goiás, tarefa que considerava essencial para a construção da Nação. Neste sentido, A Informação Goyana pode ser compreendida, segundo o pensamento de Gramsci, como um instrumento políticoeducativo a serviço das classes dirigentes; através dela, os intelectuais que a criaram e comandaram, puderam difundir a visões de mundo da classe dirigente e "imiscuir-se ativamente na vida prática, como construtor, como organizador [...]" (GRAMSCI, 1995: 09).

Por outro lado, ao assumir uma suposta neutralidade política, estes jornalistas podem ser retratados com intelectuais do tipo tradicional e vulgar no sentido apontado por Gramsci (1995), por se considerarem 'verdadeiros intelectuais' e, nesta condição, independentes da sociedade onde vivem e trabalham. No caso de A Informação Goyana, a 'neutralidade' permitiu-lhe apoiar o poder constituído por todo o período de sua publicação (1917-1935): tanto a oligarquia Caiado quanto aqueles que os afastaram o poder político estadual, depois da Revolução de Trinta, obtiveram apoio irrestrito da Revista. Em contrapartida, a Revista obteve também apoio - e subvenção financeira - dos grupos e pessoas que governaram Goiás antes e depois de 1930.

Nos marcos da compreensão gramsciana, ao traçar as bases de um programa econômico constituindo a Revista como instrumento de intervenção política, os intelectuais goianos realizaram um alargamento do campo político em dois aspectos: primeiramente, tornou mais amplo o lugar reservado ao exercício da política, a qual passa a incluir também a sociedade civil, e em segundo lugar, no que diz respeito ao conteúdo específico da função política - tradicionalmente limitada ao momento coercitivo - o momento do consenso.

No contexto do governo de Pedro Ludovico, pode-se também destacar a criação, em 1933, do Departamento de Propaganda e Vendas de Lotes. A relação entre a propaganda das riquezas goianas e sua exploração pelos capitalistas é expressa na própria junção destas duas dimensões em um só orgão público. Logo depois, em 1934, 
percebeu-se que era preciso ampliar este órgão e foi criado, em substituição ao órgão criado no ano anterior, o Departamento de Propaganda e Expansão Econômica (DPEE). Mantinha-se, porém, a dinâmica relacional entre propaganda e venda de terras uma vez que o DPEE foi estruturado em duas seções: uma Seção Cadastral que tinha como objetivo a venda de lotes na nova Capital e a outra, de Expansão Econômica, a qual tinha o objetivo de realizar a propaganda da Região e atrair, assim, a atenção de políticos e capitalistas brasileiros e estrangeiros (ASMAR, 1989).

Sintomático também destas vinculações, é o fato de Joaquim Câmara Filho, superintendente do DPEE, ter inaugurado, concomitante a sua posse, um escritório particular de vendas de lotes de Goiânia na capital mineira, Belo Horizonte. A atuação de Câmara Filho como divulgador de Goiás e de Goiânia foi intensa e pautada na afirmação categórica das riquezas naturais do estado. Em especial, Câmara Filho focalizou a existência - nem sempre verdadeiras - de jazigas de minério e pedras preciosas em abundância na Região, noticiando o encontro de minas de ouro, ferro, níquel, diamantes, etc.

Seu trabalho como divulgador das riquezas naturais e exploráveis de Goiás chegou mesmo a atingir jornais e revistas americanos, nos anos 1936 e 1937, quando chegou a publicar notas sobre a existência de minas de níquel em 125 jornais daquele País. 0 níquel, por sua vez, nunca existiu em terras goianas. Outra temática recorrente no trabalho de Câmara Filho diz respeito ao potencial agropecuário das terras goianas bem como para a capacidade de trabalho do povo goiano, o qual segundo a propaganda, era um povo que embora indolente - pacato, obediente e ordeiro, portanto, ideal para a submissão ao trabalho capitalista (ASMAR, 1989).

A construção de Goiânia aglutinava as ações deste intelectual bem como daqueles que editaram A Informação Goyana. Proposta como cidade símbolo de progresso e civilização dos sertões, Goiânia era, em si, um poderoso instrumento de propaganda que, além de atrair investimentos e pessoas, começava a proporcionar, aos moradores do estado, um sentimento de orgulho típico do ideal nacionalista. Ao divulgar, no País e também em nações estrangeiras, as possibilidades econômicas do estado de Goiás bem como o esforço que, então, se realizava em prol do progresso no hinterland brasileiro, o trabalho jornalístico realizado, então, por estes intelectuais pode ser compreendido como expressão de "um grupo que pretende (através de diversas atividades publicitárias) difundir uma concepção integral de mundo" (GRAMSCI, 1995: 201).

Finalmente, o trabalho destes intelectuais era dirigido tanto ao plano externo através do contato com jornais e revistas de outras regiões brasileiras e de outros países bem como embaixadas e consulados quanto ao plano interno através da divulgação, para a população do estado - principalmente na nova Capital em construção - aquilo que era 
publicado sobre os encantos e as riquezas goianas e sobre os resultados destas publicações. Era comum à época da construção da nova Capital que os operários fossem reunidos para ouvir a leitura, quase sempre feita pelo próprio Câmara Filho, dos textos que enviava dando notícias e também daqueles que recebia sobre o 'progresso' que chegava a Goiás (ASMAR, 1989). O povo, em sua maioria de analfabetos ou semi-alfabetizados, tomava, assim, conhecimento que Goiás começava a aparecer nacionalmente como uma região promissora, rica e articulada ao progresso que vivenciava o País.

Tais intelectuais assumiam, assim, a funções de elaborar um programa econômico para Goiás ao mesmo tempo em que trabalhavam para divulgar a visão de mundo dos dirigentes e, assim, alcançar a hegemonia cultural. Tiveram papel destacado na ocupação produtiva das terras goianas e contribuíram para que Goiânia, a nova Capital, aparecesse como porta de entrada para o adensamento populacional do estado bem como para a entrada de capital.

Quanto a Goiânia, a cidade se fez: a transferência da Capital ocorreu em 1937 e a inauguração oficial, em 1942, em um extenso programa de festividades que ficou conhecido localmente como Batismo Cultural de Goiânia, o qual pode ser interpretado, nas palavras de Candice Vidal e Souza (2002), como 'um ritual de nacionalidade em tempos de Marcha para o Oeste'. Acontecimento singular de celebração coletiva, o ritual que celebrou o surgimento da 'filha mais moça e mais bonita do Brasil'[22] concretizou-se com uma enorme força simbólica constituindo-se como um momento de marcar simbolicamente o controle humano e o usufruto social sobre o espaço da Cidade. O Batismo aparecia como oportunidade para a construção de sentidos e para acionar representações de uma modernidade que, forjada no amalgama entre o moderno e a tradição, era apresentada como ruptura com uma história de decadência, isolamento e atraso.

Aqui é possível referir-se ao que José de Souza Martins (2000) denomina 'hesitações da modernidade', a qual encontra fundamentação na forma como se constituiu, no Brasil, o propriamente nacional no momento em que se operava um expressivo movimento intelectual em busca de uma explicação do Brasil como nação; explicação que tendeu a considerar, precisamente, a cultura popular e as tradições - não as noções e saberes da modernidade - como signo da brasilidade. $O$ amalgama entre tradicional e moderno estaria, dessa forma, no Brasil, sustentado pela constituição da nação. A modernidade que se anunciava, com mais força, já em 1922 na Semana de Arte Moderna (São Paulo) ganhando visibilidade e força a partir da Revolução de Trinta, ressaltou os valores tradicionais no momento em que se intensificavam os sentimentos nacionalistas e os desejos pelo desenvolvimento, portanto, pela modernidade.

Goiânia, desse ponto de vista, pode ser pensada como expressão desse movimento. Afinal, edificada sob o prisma da modernidade, ligava-se à estrutura fundiária! 
Serviu de estratégia política para seu mentor, Pedro Ludovico, em uma época em que o governo era provisório e o governante, um interventor, indo ao encontro as eleições constituintes de 1933. Inaugurou, em Goiás, novas relações de trabalho, transformou cotidianos, alterou os sentidos da existência, implantou novos hábitos, costumes e comportamentos, forjou novas identidades, mas concomitantemente, "apresentou-se como momento contraditório da humanização [cobrando do homem] sua coisificação, [...] seu estranhamento em relação a si próprio, no ver-se pela mediação alienadora de um outro que é ele mesmo, embora não pareça" (MARTINS, 2000: 19).

Isto porque entre a cidade planejada e a cidade real, muitas interfaces. As contradições da modernidade sertaneja se avolumavam. Ilustres visitantes da cidade na década de 1930 expõem as incoerências. A pena irônica de Monteiro Lobato escancara as fragilidades da cidade: "Goiânia, cidade linda/que me encanta e seduz/ De dia, não tem água/De noite, não tem luz" (citado por Elis em Dossiê Memória Cultural, 1985: 73). LéviStrauss (1967), de passagem pela cidade, rumo a Mato Grosso, registra o estranhamento e a experiência de provisoriedade que a nova capital proporcionava aos olhos do visitante.

Visitei Goiânia em 1937. Uma planície sem fim, que parecia, ao mesmo tempo, um terreno baldio, um campo de batalha, eriçada de postes de eletricidade e de escalas de agrimensura, exibia uma centena de casas novas dispersas nos quatro cantos do horizonte. [...] nada poderia ser tão bárbaro, tão inumano quanto esse empreendimento contra o deserto [...] sentíamo-nos ali como numa estação ou num hospital, sempre passageiros e jamais residentes.

Cidade- fronteira entre dois mundos que se entrelaçavam, Goiânia - enquanto signo da modernidade brasileira - aparecia ao olhar estrangeiro como distante ou invasora ou como "[...] esfumada dificuldade da travessia" (p.26). Um cenário antimoderno, enfim! A Cidade se materializava como travessia, como incompletude, como inacabamento. Era uma promessa anunciada, embora não cumprida. Marcas da modernidade latinoamericana - como pensa José de Souza Martins (2000)! Uma arquitetura, à época, moderna[23] e a expropriação do trabalho e dos trabalhadores! A sociedade sertaneja, como lugar de uma realidade social do campo e do sertão, integrava-se a Nação como contraponto crítico e intrigante da modernidade, uma 'outra coisa', a qual desconstrói o moderno produzindo, ainda que acordo com Martins (2000: 25) "[...] uma consciência social dupla, o diverso segmentado e distribuído nos compartimentos da cultura e da vida".

\section{REFERÊNCIAS BIBLIOGRÁFICAS}

ASMAR, J. Câmara Filho: o revoltoso que promoveu Goiás. Goiânia/GO: O Popular, 1989

ANDRADE, C.R.M. de. Camilo Sitte, Camille Martins e Saturnino de Brito: traduções e transferências de idéias urbanísticas. In: RIBEIRO, L.C. de Q. \& PECHMAN, R. (orgs.). Cidade, povo e nação: gênese do urbanismo moderno. Rio de Janeiro/RJ: Civilização Brasileira, 1996, pp. 287-310 
BERNARDES, G. Construtores de Goiânia: o cotidiano no mundo do trabalho. São Paulo/SP: Depto. Ciências Sociais/PUC-SP, 1989 (Dissertação de mestrado).

BORGES, P.C.A. Formação e representações do Estado em Goiás. In: SOUZA, D.B.de (org.) Goiás: sociedade e Estado. Goiânia/GO: Cânone Editorial, 2004, pp. 187-228

BRUANT, C. Donat Agache: urbanismo, uma sociologia aplicada. In: RIBEIRO, L.C. de Q. \& PECHMAN, R. (orgs.). Cidade, povo e nação: gênese do urbanismo moderno. Rio de Janeiro/RJ: Civilização Brasileira, 1996, pp. 167-202

CAMPOS, F.I. A política tradicional em Goiás: 1930 a 1960. In: SOUZA, D.B.de (org.) Goiás: sociedade e Estado. Goiânia/GO: Cânone Editorial, 2004, pp 13-47

. Mudança da Capital: uma estratégia de poder. In: BOTELHO, T.R.(org.). Goiânia: cidade pensada. Goiânia/GO: Ed. Da UFG, 2002, pp. 169-178

. Os operários na construção de Goiânia. Jornal Opção (Encarte), ano I, v. 19, no. 11,24 out, 1980.

CHAUL, N. F. A construção de Goiânia e a transferência da capital. Goiânia/RJ: Ed. da UFG, 2001

CARVALHO, E.R.de. Construções de Goiânia. In: BOTELHO, T.R.(org.). Goiânia: cidade pensada. Goiânia/GO: Ed. da UFG, 2002, pp. 153-167

CASTRO, C. Os militares e a república: um estudo sobre cultura e política. Rio de Janeiro/RJ: Zahar, 1995

COELHO, G.N. A modernidade do Art Decó na construção de Goiânia. Goiânia/GO: Ed. da Autor, 1997.

DAHER, T. Goiânia: uma utopia européia no Brasil. Goiânia/GO: Instituto Centro-Brasileiro de Cultura, 2003.

DOSSIÊ Memória Cultural: ensaios da história de um povo. Goiânia/GO: PMG, 1985

ELIS, B. Goiás em sol maior. Goiânia/GO: Poligráfica, 1985

GRAMSCI, A. Cadernos do Cárcere. Rio de Janeiro/RJ: Civilização Brasileira, 1999. . Maquiavel, a política e o Estado. Rio de Janeiro/RJ: Civilização Brasileira, 1991 $\overline{\text { Brasileira, }}_{1995}$ Os intelectuais e a organização da cultura. Rio de Janeiro/RJ: Civilização . Concepção dialética da história. Rio de Janeiro/RJ: Civilização Brasileira, 1978

HOLSTON, J. A cidade modernista: uma crítica de Brasília e sua utopia. São Paulo/SP: Companhia da Letras, 1993

IANNI, O. Estado e planejamento econômico no Brasil (1930-1970). Rio de Janeiro/RJ: Civilização Brasileira, 1977. 
LÉVI-STRAUSS, C. Tristes trópicos. São Paulo/SP: Ed. Anhembi, 1967.

NEPOMUCENO, M A. O papel político-educativo de A Informação Goyana na construção da nacionalidade. Goiânia/GO: Ed. da UFG, 2003.

MONTEIRO, O.S. do N. Como Nasceu Goiânia. Goiânia/GO: 1942

PALACÍN, L. Quatro tempos da ideologia em Goiás. Goiânia/SP: Cerne, 1986

PEREIRA, E. M. C.M. Goiânia, filha mais moça e bonita do Brasil. In: BOTELHO, T.R. (org.). Goiânia: cidade pensada. Goiânia/GO: Ed. Da UFG, 2002, pp. 13-70

PEREIRA, M. da S. Pensando a metrópole moderna: os planos de Agache e Le Corbusier para o Rio de Janeiro. In: RIBEIRO, L.C. de Q. \& PECHMAN, R. (orgs.). Cidade, povo e nação: gênese do urbanismo moderno. Rio de Janeiro/RJ: Civilização Brasileira, 1996, pp. 363-376

REVISTA A Informação Goyana. Governo do estado de Goiás, Goiânia/GO: Cerne, 1979 (Rerprodução fac-simíle da coleção completa da revista publicada no Rio de Janeiro por Henrique Silva e Americano do Brasil, no período 1917-1935).

RIBEIRO, L.C.de Q. Transferências, empréstimos e traduções da formação do urbanismo no Brasil. In: RIBEIRO, L.C. de Q. \& PECHMAN, R. (orgs.). Cidade, povo e nação: gênese do urbanismo moderno. Rio de Janeiro/RJ: Civilização Brasileira, 1996, pp. 15-21

MARTINS, J. de S. Capitalismo e tradicionalismo. São Paulo/SP: Pioneira, 1975

A sociabilidade do homem simples. São Paulo/SP: Hucitec, 2000

SILVA, A.L. A Revolução de 30 em Goiás. Goiânia/SP: Cânone Editorial/AGEPEL, 2001

SILVA, F.C.T. d. Vargas e a questão agrária. In: Seminário sobre Vargas e o desenvolvimento nacional. Acesso em 21/02/2002. In:

www.bndes.gov.br/resumo_gvargas.

VIDAL E SOUZA, C. Batismo cultural de Goiânia: um ritual da nacionalidade em tempos de Marcha para o Oeste. In: BOTELHO, T.R. (org.) Goiânia: cidade pensada. Goiânia/GO: Editora da UFG, 2002, pp. 71-102

* Mestre em Doutoranda no Programa de Pós-Graduação em Educação da Universidade Federal Fluminense

[1] Texto apresentado para avaliação na disciplina Teoria e Educação I - Seminários Avançados - a qual consta na grade curricular do curso de doutorado do Programa de Pós-graduação em Educação, da FE/UFF - no primeiro semestre de 2005, sob a coordenação da profa. Dra.. Sonia Rummert.

[2] Foram contratados para tal empreitada, primeiramente, Atílio Correia Lima, primeiro brasileiro que realizou cursos de especialização em urbanismo na França, e depois, o engenheiro Armando Augusto de Godoy, nome de vulto na intensa discussão sobre a reforma das cidades que, então, empolgava certos setores da intelectualidade e da política brasileiras (DAHER, 2003).

[3] Hinterland era a denominação comumente utilizada - por um grupo de intelectuais goianos que editou no Rio de Janeiro, de 1917 a 1935, a revista A Informação Goyana - para designar a região centro-oeste e, particularmente, o estado de Goiás. 
[4] Fragmento do Relatório apresentado pelos irmãos Coimbra Bueno da Superintendência Geral das Obras de Goiânia - ao Sr. Oscar Campos Junior, Diretor Geral da Fazenda, em junho de 1936 (MONTEIRO, 1942).

[5] O historiador Eugênio Carvalho (2002) considera esta interpretação bastante polêmica, embora, não desconsidere que a força deste imaginário na construção de Goiânia questionando, tão somente, sua preponderância sobre outras motivações. Basicamente, o que este historiador vem questionar se refere as possibilidades de uma mentalidade coletiva dominante - impregnada pelo sentimento de inferioridade dos goianos - ter atravessado quase dois séculos e influenciado os idealizadores de Goiânia, na década de 1930. Chama atenção, ainda, para o fato dessa perspectiva ser a mesma contida no discurso desses idealizadores, colocando uma questão: "Até que ponto esta não seria uma perspectiva ideológica legitimadora e justificadora das transformações desejáveis pelos partidários da nova capital [no século XX]?".

[6] Goiás teve sua história atravessada pela presença de um imaginário nacional repleto de valorações negativas expressas na idéia de decadência, atraso, preguiça e indolência, ignorância. Aos nativos, em conseqüência, as adjetivações roceiro, atrasado, preguiçoso, analfabeto expressam uma visível negatividade, embora, o nacionalismo brasileiro - que considerou que o verdadeiro Brasil era o interior tenha agregado a estas representações a grandiosidade épica do sertanejo, esta uma imagem forjada, sobretudo, através de uma literatura nacionalista e de caráter evolucionista, a qual teve na obra de Euclides da Cunha, Os Sertões, seu maior expoente (PEREIRA, 2002).

[7] È assim que Paulo Figueiredo - repórter, redator e um dos principais colaboradores da Revista Oeste, publicada em Goiás, autor de artigos sempre em defesa do Estado Novo e de Pedro Ludovico - se refere à Goiânia no artigo O Brasil comeu espinafre. Paulo Figueiredo foi também professor da Faculdade de Direito de Goiás, promotor público de Bonfim (1940), procurador geral da Fazenda, advogado do Estado, membro presidente do Conselho Administrativo (órgão que substituiu a Assembléia Legislativa durante o Estado Novo) e procurador-geral do estado junto ao Governo Federal (PEREIRA, 2002)

[8] O primeiro automóvel somente adentrou as terras goianas no ano de 1906, exatamente, em Itumbiara, cidade-fronteira com a região do Triângulo Mineiro, em Minas Gerais (CHAUL, 2001).

[9] Benedicta Cipriano Gomes, a Dica, moradora do vilarejo de Lagoa, nas proximidades de Pirenopólis. Realizando curas, milagres e previsões, Dica atraiu para o vilarejo cerca de 500 pessoas que ali se fixaram atraídos pelos feitos da 'Santa'. Dica, por sua vez, acreditava que tinha uma missão libertadora entre os pobres e obteve a obediência daqueles que se fixaram em Lagoa que a viam como 'guia'. Em terra de fazendeiros, Dica afirmava que a terra era propriedade de Deus, questionando os títulos de propriedade e afirmando que a terra deveria ser trabalhada coletivamente sendo que seus frutos deveriam ser divididos entre todos. Dica e seu 'reduto', evidentemente, começaram a incomodar os donos do poder (entre eles, a Igreja) e iniciou-se uma intensa campanha de difamação do Movimento através do jornal O democrata. Um processo judicial foi movido contra Dica que foi presa e condenada e o 'reduto' foi tomado, com mortes, pelas forças policiais do estado sob o comando de Brasil de Ramos Caiado (NEPOMUCENO, 2003).

[10] São José do Duro (hoje, Dianópolis) era um vilarejo situado no norte de Goiás, formado por 30 casas e uma igreja cujo chefia política era da família Wolney, antiga aliada dos Caiado. Porém, os Caiado, a partir, de 1912 realizaram, não se sabe nem porque, o expurgo de Abílio Wolney da política, processo que se estendeu até 1919 quando Abílio foi, finalmente, afastado da vida pública. Sua reação transformou a Vila do Duro em um campo de tensão e morte até que, aliando-se a outras famílias da Região, os Caiado liquidaram violentamente a família Wolney (NEPOMUCENO, 2003). Abílio, porém, escapou com vida, fugiu para a Bahia onde se tornou, depois de 1930, prefeito de Barreiras.

[11] Artigo-programa ou Editorial da Revista $A$ Informação Goyana, em agosto de 1917. Este editorial foi reproduzido, em qualquer alteração, por todo o período (1917-1935) de circulação da Revista. A respeito ver em Nepomuceno (2003).

[12] Concomitantemente, um movimento cultural de cunho nacionalista veiculava a idéia que era preciso considerar o sertão como uma "categoria essencial para o entendimento da nação". Esse movimento nacionalista - que repudiava a importação de modelos estrangeiros e defendia a construção de uma cultura essencialmente brasileira, buscando a valorização do interior, do sertão - foi contemporâneo do Modernismo, o qual considerava o modelo civilizatório do estado de São Paulo, especialmente, a Capital paulista, como exemplo do progresso brasileiro. O litoral, representado basicamente pela cidade do Rio de Janeiro, foi considerado, por muitos intelectuais, como decadente por ser "um consumidor de idéias, de sistemas políticos e de modas importadas" (PEREIRA, 2002:24). O sertão, ao contrário, foi associado a uma imagem do verdadeiro. 
[13] De acordo com Campos (2004: 11), "[...] a intervenção de Minas Gerais na política de Goiás sugere uma certa continuidade das divergências daquele estado com São Paulo. De há muito se observa que o Palácio da Liberdade apoiava líderes da oposição goiana aos grupos dos Caiados. São Paulo, por sua vez, prestigia a situação goiana. Em 1928, a convite daquele estado, Goiás participa do convênio do café".

[14] Segundo Campos (1980:), "[...] considerando-se que, em 1940 [portanto, quase uma década após o inicio da construção], das 52 cidades goianas, apenas 4 (Goiânia, Anápolis, Goiás e Ipameri) tinham mais de 4 mil habitantes $[\ldots]$.

[15] As moradias dos operários compunham-se ranchos de capim, pequenas casas de madeira e barracões de depósitos de material de construção.

\section{[16] Entrevista concedida ao projeto Memória Operária na Construção de Goiânia (apud CHAUL, 2001)}

[17] Esta prática também se estendeu às famílias de classe média que começaram a surgir na Região no início dos anos 1920. Boa parte dos jovens goianos das famílias abastadas realizava estudos superiores no Rio de Janeiro, principalmente, na Faculdade de Medicina do Rio de Janeiro e na Escola Militar da Praia Vermelha (NEPOMUCENO, 2003).

[18] Ainda não existem estudos significativos sobre a intelectualidade goiana e seu papel no desenvolvimento histórico do estado e mesmo do Brasil. Uma honrosa exceção é o trabalho de Maria de Araújo Nepomuceno sobre a Revista $A$ Informação Goyana, o qual focaliza o papel destes intelectuais, através da Revista em questão, na construção da nacionalidade e de forma mais específica, na construção da pátria geográfica.

[19] Em 1891, foi publicado o único número da Revista Brazil Central, a qual foi definida em seu editorial de lançamento como "revista mensal consagrada aos interesses de Goyaz". O projeto desta Revista foi idealizado no interior da Escola Militar da Praia Vermelha quando Henrique Silva e outros intelectuais goianos freqüentaram esta Escola (NEPOMUCENO, 2003).

[20] Este editorial - que constitui em 'artigo-programa da Revista - foi reproduzindo quase integralmente pela Revista A Informação Goyana em todos os números publicados durante sua existência (1917-1935).

[21] Henrique Silva, o editor e principal jornalista de A Informação Goyana durante toda a sua existência, era militar formado na Escola Militar da Praia Vermelha onde predominava a filosofia positivista de Augusto Comte, principalmente, depois da entrada como professor de matemática, de Benjamin Constant (CASTRO, 1995).

[22] È assim que Paulo Figueiredo - repórter, redator e um dos principais colaboradores da Revista Oeste, publicada em Goiás, autor de artigos sempre em defesa do Estado Novo e de Pedro Ludovico - se refere à Goiânia no artigo O Brasil comeu espinafre. Paulo Figueiredo foi também professor da Faculdade de Direito de Goiás, promotor público de Bonfim (1940), procurador geral da Fazenda, advogado do Estado, membro presidente do Conselho Administrativo (órgão que substituiu a Assembléia Legislativa durante o Estado Novo) e procurador-geral do estado junto ao Governo Federal (PEREIRA, 2002).

[23] Refiro-me a arquitetura art decó que predominou na construção de Goiânia. Este estilo - ou antes, este estilema - arquitetônico é hoje, considerado, proto-modernista ou pré-moderno. Seu desenvolvimento ocorreu ns anos 1930, com apogeu na década de 1940, apresentando ainda alguma manifestações tardias na década de 1950. Sua maior característica está na sensação de monumentalidade independente das grandes dimensões e volumes encontrados na arquitetura oficial de outros períodos". É esse sensação racionalista de monumentalidade que vai despertar o interesse das ditaduras e estados totalitários no período em questão bem como de grandes conglomerados financeiros (COELHO, 1997: 19). 